\title{
5. State funding of private education: the role of human rights
}

\section{Sandra Fredman}

\section{INTRODUCTION}

The rapid spread of low-cost for-profit schools in many countries raises many questions for human rights compliance. The recognition of the responsibility of the State to provide education for every child was one of the most important forces for progress in the twentieth century. This process has culminated in the establishment of the fundamental right of every child to receive free and compulsory primary education, with progressive realization of free secondary education. Free and compulsory education serves many purposes, such as combating child labour and facilitating the enjoyment of other rights. But can the State discharge its obligation to provide free and compulsory education by funding private actors to do so, and if so, under what conditions? This is the central question in this chapter.

The chapter will show that, although the State is required to permit private education, it is not necessarily obliged to fund such education. On the other hand, the State is not prohibited from funding private education; indeed, it might have this duty if doing otherwise would be discriminatory. International human rights instruments consistently reiterate that the obligation to respect, protect, and fulfil the right to education remains on the State, regardless of whether it has permitted or funded private providers. ${ }^{1}$ The real question therefore concerns the conditions under which State funding of private education should be permitted. The liberty of individuals and bodies to establish and direct educational institutions is subject to compliance with minimum standards laid down by the State 
and to the core values of the right to education. The chapter elaborates on the duties of the State when it permits private education, and how these duties manifest when the State provides funding for such education. The chapter pays specific attention to the duty not to discriminate.

Section I of the chapter considers whether funding of private providers breaches human rights. This section first establishes that there is a duty to permit private schools; second, that there is generally no State duty to fund private schools; and, third, that nevertheless there is no absolute prohibition on State funding for private schools. Section II considers the conditions under which such funding should be provided to ensure compliance with human rights.

Numerous different ways exist in which the State funds private sector involvement in education provision. They range from contracting out the provision of materials such as textbooks and digital technology; to construction of buildings; to subsidies of individual pupils in private schools; to partnerships with private providers over the management of schools; to simply subsidizing private education providers, including religious, linguistic, or other minority schools. Funding mechanisms can include giving charitable status to private schools, thereby allowing them to pay less tax; or favourable contract terms. This chapter does not aim to analyse each of these, but instead to set out the main principles as expounded by international, regional, and selected domestic human rights instruments. The specific type of funding in individual cases needs to be assessed in these terms.

It should be acknowledged at the outset that there is very little express material in the legal sources investigated in this chapter as to the conditions under which public funding of private schools is permissible. There are clear principles which identify the continuing State responsibility in relation to private provision, but these principles apply whether or not the State is providing funding. This chapter therefore aims to extrapolate from the general principles applicable to State responsibilities for the right to education in order to answer this question. To do so, the chapter draws on a number of different sources at international, regional, and municipal level. Each of these sources is based on a different textual mandate and might have varying degrees of legal authority. The aim is therefore not to produce a definitive legal analysis, but to develop a set of principles, and show how they relate to existing legal sources. 


\section{IS PUBLIC FUNDING OF PRIVATE PROVIDERS COMPLIANT WITH HUMAN RIGHTS LAW?}

\section{i. Is There a Duty to Permit Private Education?}

All the major international human rights instruments include provision for private education. There is no independent right to education in the International Covenant on Civil and Political Rights (ICCPR). Nevertheless, Article 18 (freedom of conscience, thought, and religion) includes a provision requiring States to 'have respect for the liberty of parents and ... legal guardians to ensure the religious and moral education of their children in conformity with their own convictions'. ${ }^{2}$ The International Covenant on Economic, Social and Cultural Rights (ICESCR) is somewhat broader: Article 13 on the right to education includes an express provision requiring respect for the 'liberty of individuals and bodies to establish and direct educational institutions', subject to the values stated in the Covenant and to minimum standards. ${ }^{3}$ The UN's Convention on the Rights of the Child (CRC) has a very similar provision. Similarly, the European Convention on Human Rights (ECHR), which states that no one should be denied the right to education, goes on to provide that the State must 'respect the right of parents to ensure such education and teaching in conformity with their own religious and philosophical convictions'. ${ }^{4}$

The Hague Recommendations on the education rights of national minorities take this somewhat further. They declare that States should not impose unduly onerous legal and administrative regulatory requirements which might hinder the enjoyment of the right to found private schools. ${ }^{5}$ The right to establish private educational establishments is also protected in domestic constitutions. For example, the South African Constitution provides for the right to establish independent private educational institu-

ICCPR 1966, Article 18(4).

ICESCR, 1976 Article 13(4); see also CRC, Art 29(2).

$4 \quad$ ECHR Protocol 1 Article 2; contrast the absence of such a provision in the African Charter on Human and People's Rights (1981).

5 The Hague Recommendations regarding the education rights of national minorities (October 1996), Recommendations 8, 9 and 10 and explanatory notes to Recommendations 8-10. See https://www.osce.org/hcnm/32180 (accessed 13 April 2018). 
tions. ${ }^{6}$ Similarly, under the Constitution of India, religious and linguistic minorities have the right to establish and administer educational institutions of their choice. ${ }^{7}$

These provisions can be regarded as fulfilling the freedom dimension of the right to education. The freedom dimension of the right is crucial to protect parental rights to opt out of State education, particularly where there is a risk that the State might use the education system as propaganda or to suppress minority religions. This means that the State is under an obligation, at the very least, to permit private provision of education. However, the freedom aspect should not obscure the social and equality dimensions of the right to education. Education as a social right, which is enshrined in the ICESCR, goes beyond protection against State interference in the content or provision of education, and establishes a positive right to free and compulsory education, particularly at the primary level. ${ }^{8}$ Education as an equality right means that States should guarantee that the right to education can be exercised without discrimination on grounds such as race, religion, gender or disability. ${ }^{9}$ The question of whether the State is either required or entitled to fund private schools must also account for the maximization of these aspects.

\title{
ii. Is There a Duty to Fund Private Education?
}

The freedom aspect of the right to education means that the State must permit private education. It does not, however, necessarily mean that the State must fund private education. ${ }^{10}$ In the Belgian Linguistics case, the European Court of Human Rights (ECtHR) refused to hold that there was any requirement for the State to establish at their own expense or to subsidize education of any particular type or at any particular level. ${ }^{11}$ The Human Rights Committee (HRC) has similarly held that a State party is under no obligation under the ICCPR to provide public subsidies for

\author{
South African Constitution, 1996, s 29(3). \\ Constitution of India, 1949, Article 30. \\ ICESCR, Article 13. \\ ICESCR, Article 2(2); CRPD Article 5.
}

10 It was noted above that there are myriad ways in which the State can fund private education. This subsection sets out the main principles, which might need to be applied in specific form to different types of funding.

11 Belgian Linguistic Case (No 2) (1979-80) 1 EHRR 252 (European Court of Human Rights) para [3]. 
private education where it has a comprehensive public school system in place. ${ }^{12}$ In two communications against Sweden, the Committee rejected the claim that Sweden's refusal to provide financial assistance towards the cost of private schooling constituted discrimination in breach of the ICCPR.

In the first case, Lindgren $v$ Sweden, ${ }^{13}$ the applicants argued that because of the compulsory nature of school attendance, the State should offset the cost of textbooks and school meals at private schools. They also claimed that the State discriminated between their children and pupils of public schools contrary to Article 26 ICCPR, which establishes equality before the law and the right not to be discriminated against on specific grounds. The Committee rejected their claim as the parents were free to take advantage of public sector schooling. Since the State made public schooling available to all children, including a variety of ancillary benefits, such as free transport by bus, free textbooks, and school meals, the State party was not under an obligation to provide the same benefits to private schools. The decision to use private education was a free choice recognized by the State party. But such free choice understandably brought with it consequences, namely payment of tuition, transport, textbooks, and school meals. The Committee concluded that a State party could not be deemed to discriminate against parents who freely choose not to avail themselves of benefits open to all. Therefore, the State had not violated Article 26 by failing to provide the same benefits to private school pupils as to those at public schools.

In the second case, Carl Henrik Blom v Sweden, the author challenged his government's refusal to provide financial aid for him to attend a private Rudolf Steiner School. He claimed that this constituted discrimination against pupils in private schools in violation of the equality guarantee in Article 26 ICCPR. At that time, Swedish law provided that the State was not obliged to provide public funding to private schools and that funding could only be provided to schools subject to State supervision. The school in question had not yet been placed under such supervision. The HRC decided that the State party could not be deemed to act in a discriminatory manner if it did not provide the same level of

12 Lindgren v Sweden, Communication No 299/1988; UN Doc. CCPR/ C/40/D/298-299/1988 (1990); Carl Henrik Blom v Sweden, Communication No. 191/1985, UN Doc CCOR/OP/2 at 216 (1990).

13 Lindgren v Sweden, Communication No 299/1988; UN Doc. CCPR/ C/40/D/298-299/1988 (1990). 
subsidy to private and public education when the private system is not subject to State supervision. It therefore rejected the claim. ${ }^{14}$ As summarized by the concurring opinion in the later case of Waldman, while the Committee in these cases 'left open the question of whether the Covenant entails, in certain situations, an obligation to provide some public funding for private schools, it concluded that the fact that private schools, freely chosen by the parents and their children, do not receive the same level of funding as public schools does not amount to discrimination. ${ }^{15}$

A similar principle was established in South Africa, although using very different reasoning processes. In a case in 2013, private schools contested the withdrawal of State subsidy of private schools as a breach of contract and of the right to education. The South African Constitutional Court held that no binding contractual right to such subsidies existed. Provided the State provided reasonable notice and fulfilled existing obligations, it was entitled to withdraw such funding. ${ }^{16}$ Similarly, the Hague Recommendations on the education rights of national minorities, while declaring that private schools should not be prevented from seeking resources from all domestic and international sources, nevertheless find no formal obligation to fund such schools. ${ }^{17}$

Although the State has no obligation to fund private schools, if it does choose to do so, it cannot discriminate on the basis of a prohibited grounds such as race, religion, or gender. In its General Comment on Education, the Committee on Economic, Social and Cultural Rights (CESCR) asserts that a State party has no obligation to fund educational institutions established under Article 13(4) of the Covenant. However, if it does make a financial contribution to private educational institutions, it must do so without discrimination on any of the prohibited grounds,

14 Carl Henrik Blom v Sweden, Communication No. 191/1985, UN Doc $\mathrm{CCOR} / \mathrm{OP} / 2$ at 216 (1990).

15 Arieh Hollis Waldman v Canada HRC, Communication No. 694/1996 (5 November 1999, UN Doc CCPR/C/67/D/694/1996) concurring opinion para 3; at the European level, see also Jordebo $v$ Sweden, upholding the State's right to refuse to recognize a private school for the purposes of fulfilling the duty to provide private education: Application No. 11533/85 (admissibility decision).

${ }_{16}$ KwaZulu-Natal Joint Liaison Committee $v$ MEC Department of Education [2013] ZACC 10 (South African Constitutional Court).

17 The Hague Recommendations regarding the education rights of national minorities (October 1996), Recommendations 8, 9 and 10 and explanatory notes to Recommendations 8-10. See https://www.osce.org/hcnm/32180 (accessed 13 April 2018). 
namely race, colour, sex, language, religion, political or other opinion, national or social origin, property, birth, or other status. ${ }^{18}$ Similar legal authority exists at domestic level. Thus, the Constitution of India prohibits the State from discriminating when granting aid to an educational institution on the grounds that it is under the management of a religious or linguistic minority. ${ }^{19}$ A similar conclusion was reached by the US Supreme Court in a recent case. Giving the opinion of the Court, Chief Justice Roberts held: 'A state need not subsidize private education. But once a state decides to do so, it cannot disqualify some private schools solely because they are religious. ${ }^{20}$

The HRC has echoed this approach, holding that, under the ICCPR, if the State chooses to fund some religious schools, it must make this funding available without discrimination to all religious groups. Thus, in its decision in Waldman, the HRC found a violation of Canada's duty not to discriminate, since Roman Catholic schools were given full and direct public funding, whereas other religious schools were not. The Committee therefore upheld a complaint of discrimination by a member of the Jewish faith who enrolled his children in a private Jewish school in Ontario. According to the Committee: 'The Covenant does not oblige State parties to fund schools which are established on a religious basis. But if a State party chooses to provide public funding to religious schools, it should make this funding available without discrimination. ${ }^{21}$ It therefore found a violation of the author's rights under Article 26 of the Covenant to equal and effective protection against discrimination.

This also raised the question of whether the State is required to establish a public minority school, or can discharge its duty not to discriminate by providing comparable public funding to a private minority school. In his concurring opinion, Martin Scheinin stated that one legitimate criterion would be whether there were sufficient minority children to make a public minority school a viable part in the overall system of education. In this case, since there were sufficient Jewish children, it was discriminatory to provide only indirect funding for the Jewish school as compared to full direct funding provided to public Roman Catholic schools

18 ICESCR Gen Comment 13 on the Right to Education (1999), para 54.

19 Constitution of India, 1949, Article 30.

20 Espinoza v Montana No.18-1195 (Decided June 30, 2020). See https:// www.supremecourt.gov/opinions/19pdf/18-1195_g314.pdf (15 July 2020).

$21 \quad$ Arieh Hollis Waldman v Canada, HRC Communication No. 694/1996 (5 November 1999, UN Doc CCPR/C/67/D/694/1996) Para 10.6. 
in Ontario. This can be contrasted with the earlier case of Tadman, in which parents of children from a variety of non-Catholic faiths claimed that either funding should be provided for all other religious schools, or no funding should be provided for Roman Catholic schools. The HRC found that the claim was inadmissible. Because the parents were asking for funding to be withdrawn from Catholic schools, they had lost nothing and therefore could not be regarded as victims. ${ }^{22}$

On the basis of the concurring decision in Waldman, Beiter argues that State parties have an obligation either to provide for religious education of minority religious groups in public schools or alternatively to grant State funding to private schools operated by such groups if a sufficient number of children would attend such a school. ${ }^{23} \mathrm{He}$ further supports this by reference to Article 27 ICCPR which gives persons belonging to ethnic, religious, or linguistic minorities the right to enjoy their own culture, practise their own religion, and use their own language. ${ }^{24}$ However, this principle has not been clearly established by the HRC. ${ }^{25}$

\section{iii. Is the State Prohibited from Funding Private Education?}

This raises the key question of whether the State is prohibited from funding private providers. At domestic level, this depends on the wording of the national constitutional right to education. Some human rights instruments specifically permit the State to fund private providers. The South African Constitution expressly entitles the State to provide State subsidies for independent educational institutions. ${ }^{26}$ In India, the Right to Education legislation enacted under the recently amended Article $21 \mathrm{~A}$ of the Indian Constitution includes as a central feature the duty of private unaided institutions to make 25 per cent of the places available to children from disadvantaged sectors of society. The State pays the

22 Tadman and Ors $v$ Canada, Admissibility, Communication No 816/1998, UN Doc CCPR/C/67/D/816/1998, IHRL 3616 (UNHRC 1999), 29th October 1999. For an interesting contrast in Canada, see the Good Spirit case (2017 SKQB 109). Meghan Campbell, “A New Ground Of Discrimination: Rural Remoteness?” (OxHRH Blog, 5 June 2017). See http://ohrh.law.ox.ac.uk/a-new -ground-of-discrimination-rural-remoteness (accessed 15 July 2020).

${ }_{23}$ K. Beiter, The Protection of the Right to Education by International Law (Martinus Nijhoff Publishers, 2006), 452.

$24 \quad$ Ibid, 453.

25 Human Rights Committee Communication No. 1155/2003 (Norway).

26 South African Constitution, S29(4). 
private school the same amount per capita as it would spend on educating the child in the public sector. The private school is expected to subsidize the remainder, and to give each child equal access to all the facilities at the school. The statute was challenged by private proprietors as a breach of their freedom of occupation. The Supreme Court upheld the statute, except in relation to minority schools, which it held had the right to retain their minority character. There was, however, no challenge to the use of public funds for children in the private sector. ${ }^{27}$

By contrast, in several US States, State courts have held that the State Constitution bars the use of money intended for public schooling to be used on a voucher system to send individual learners to private schools. The Constitution of Louisiana states: 'The legislature shall provide for the education of the people of the State and shall establish and maintain a public educational system. ${ }^{28}$ It requires the legislature to 'fully fund the current cost to the state' of 'a minimum foundation program of education in all public elementary and secondary schools', and the 'funds appropriated shall be equitably allocated to parish and city school systems' ${ }^{29}$ The Supreme Court of Louisiana held that this meant that funds approved for the minimum foundation programme could not be diverted to non-public schools or other non-public course providers. On the other hand, the Constitution specifically permits the funding of textbooks for students attending non-public schools. ${ }^{30}$

A similar and even more emphatic conclusion was reached in relation to the Florida Constitution, which provides that 'It is ... a paramount duty of the state to make adequate provision for the education of all children residing within its borders.' It goes on to state: 'Adequate provision shall be made by law for a uniform, efficient, safe, secure, and high-quality system of free public schools. ${ }^{31}$ In Bush v Holmes, the Supreme Court of Florida struck down the statutory provision of school vouchers, which used public funds to allow students to obtain a private school education from kindergarten to grade 12 as an alternative to public school edu-

$27 \quad$ Society for Un-aided Private Schools of Rajasthan v. Union of India (2012) 6 SCC 1 (Indian Supreme Court). The responsibility for determining schools with minority status lies at the level of individual Indian states.

\footnotetext{
$28 \quad$ La. Const. art. VIII, $\S 1$.

29 Constitution of Louisiana, Article VIII, $\S 13(\mathrm{~B})$.

$30 \quad$ Louisiana Federation of Teachers $v$ State of Louisiana 118 So.3d 1033

(2013) (Supreme Court of Louisiana).
}

31 Florida Constitution Article IX, section 1(a). 
cation. ${ }^{32}$ The Court held that the programme diverted public funds into private systems in competition with free public schools, which were the sole means set out in the Constitution to provide for education of children in the State. The diversion "not only reduces money available to the free schools, but also funds private schools that are not "uniform" when compared with each other or the public system. Many standards imposed by law on the public schools are inapplicable to the private schools receiving public monies. ${ }^{33}$ The Court emphasized that this did not diminish the basic right of parents to educate their children as they saw fit. Only when the private school option depended on public funding was the choice limited. ${ }^{34}$

It should be noted that these principles are not necessarily replicated at Federal level in the US. The US Supreme Court has held that education is not a fundamental right, and refused to find that funding arrangements based on local taxes were in breach of the right to equality under the Fourteenth Amendment, even though they clearly discriminated against poorer residents. ${ }^{35}$ Moreover, the Court seems to be moving away from the strict principle that religious institutions should be excluded from government grant programmes. Indeed, a case in 2017 required the State of Missouri to include a preschool and day-care centre run by Trinity Lutheran Church in its programme to provide grants to schools for playground surfaces made from recycled tyres. The exclusion it was held, 'expressly discriminates against otherwise eligible recipients by disqualifying them from a public benefit solely because of their religious character. ${ }^{36}$

At international level, it is difficult to find a definitive statement on the permissibility of public funding for private providers. However, there are some clear indications that State funding of private providers is not prohibited. As we have seen, the CESCR has stated that a State party has no duty to fund private educational institutions. But if it does elect to

\footnotetext{
32 Bush v Holmes 919 So.2d 392 (2006) (Supreme Court of Florida).

33 Ibid, 398.

$34 \quad$ Ibid.

35 San Antonio Independent School District v. Rodriguez 411 U.S. 959 (1973) (U.S. Supreme Court).

36 Trinity Lutheran Church v Comer 137 S. Ct. 2012; Espinoza v Montana No.18-1195 (Decided June 30, 2020). See https://www.supremecourt .gov/opinions/19pdf/18-1195_g314.pdf (accessed 15 July 2020).
} 
make a financial contribution, it should do so without discrimination. ${ }^{37}$ This strongly suggests that funding of private institutions is not prohibited. Similarly, the more recent CESCR General Comment on State obligations in the context of business activities states that privatization is not in itself prohibited, but expresses concern that private education is not affordable to many individuals. ${ }^{38}$ The Convention on the Elimination of all Forms of Discrimination Against Women (CEDAW) General Recommendation on education similarly makes no clear statement suggesting that the funding of private providers is prohibited. Thus, the key issue is not whether State funding of private providers is prohibited, but what conditions should be attached to such funding. It is this question to which we now turn.

\section{UNDER WHAT CONDITIONS IS PRIVATE FUNDING PERMISSIBLE?}

Little definitive material exists in the legal sources investigated in this chapter about the conditions under which private funding of education is permissible. There are clear principles articulating State responsibility in relation to private provision, but these principles apply whether or not the State is providing funding. This section therefore aims to extrapolate from the general principles applicable to State responsibility for the right to education to answer this question. In order to do so, the chapter draws on a number of different sources at international, regional, and municipal levels. As mentioned above, each of these sources is based on a different textual mandate and might have varying degrees of legal authority. The aim is therefore not to produce a definitive legal analysis, but to develop a set of principles, and show how they relate to existing legal sources.

The central principle is that the State remains responsible for the provision of education. This continues to be the case even if parents exercise their choice to find alternative education for their children or individuals choose to establish their own institutions. Whether it funds private providers or not, the State retains its responsibility to ensure that all providers conform to educational standards set for schools, and

$37 \quad$ CESCR General Comment 13 (1999), para 54.

38 General comment No. 24 (2017) on State obligations under the International Covenant on Economic, Social and Cultural Rights in the context of business activities, para 21 . 
fulfil the primary values informing the right to education, as set out, for example in ICESCR.$^{39}$ This is clearly established under both the CESCR and the CRC. Article 13(3) ICESCR states that parents' liberty to choose schools must be respected provided they conform to 'such minimum educational standards as may be laid down or approved by the State. ${ }^{40}$ Under Article 13(4), the right to establish and direct educational institutions is additionally subject to the requirement to respect the principles in Article 13(1), ${ }^{41}$ namely that education should 'be directed to the full development of the human personality and the sense of its dignity, and shall strengthen the respect for human rights and fundamental freedoms'. In addition, education should:

enable all persons to participate effectively in a free society, promote understanding, tolerance and friendship among all nations and all racial, ethnic or religious groups, and further the activities of the United Nations for the maintenance of peace..$^{42}$

The CRC takes a similar approach. Thus, the liberty of individuals and bodies to establish and direct educational institutions should always be subject to minimum standards laid down by the State and the general principles applicable to all institutions. The CRC expands the principles in the ICESCR to include the development of respect for the 'child's parents, his or her own cultural identity, language and values, for the national values of the country in which the child is living, the country from which he or she may originate, and for civilizations different from his or her own' ${ }^{43}$ In addition, education should be directed to 'the preparation of the child for responsible life in a free society, in the spirit of understanding, peace, tolerance, equality of sexes, and friendship among all peoples, ethnic, national and religious groups and persons of indigenous origin'; and to 'the development of respect for the natural environment'. ${ }^{44}$

The duty to monitor private institutions and insist on minimum standards applies to States regardless of whether public funding for pupils attending these institutions is provided. Given that the State is permitted 
to provide funding if it so chooses, the question arises of whether the State accrues extra obligations when it does provide public funding. The State's continuing obligations are best analysed under the three-fold duty to respect, protect, and fulfil the right to education. Under each heading, it will be asked whether the State has additional or different duties when it provides funding for private education.

\section{i. Duty to Respect}

The State's duty to respect entails a duty not to obstruct the enjoyment of the right to education. It is most usually manifested as a prohibition on indoctrination and a duty to permit parents and individuals to establish schools to educate their children according to their convictions, as we have seen. State funding to private providers arguably creates further obligations. In particular, the duty not to obstruct education means that public funding to private providers should not undermine the State's own provision for education through public funding. As highlighted in the Louisiana and Florida cases (as well as the Abidjan Principles), the use of public funds for private education must not divert public funds away from public education which would otherwise undermine the State's primary responsibility to provide free and compulsory quality education to all children.

The CESCR has highlighted this issue in its Concluding Observations on several countries in recent years. In its Concluding Observations in respect to Kenya in 2016, the CESCR expressly linked lack of investment in public schooling to the proliferation of low-cost private schools. ${ }^{45}$ As discussed in Chapter 9 of this volume, the spread of such schools has in turn led to segregation and discriminatory access to education, particularly for disadvantaged and marginalized children, such as those living in informal settlements and semi-arid areas. ${ }^{46}$ The Committee made it clear that the State has primary responsibility for the right to education. It called on the State to take all measures necessary to strengthen its public education sector, including increasing the budget allocated to primary legislation, and improving access to and quality of primary education for all without hidden costs. ${ }^{47}$

45 CESCR Kenya Concluding Observations (2016).

46 CESCR Kenya Concluding Observations (2016).

47 CESCR Kenya Concluding Observations (2016), paras 57-58. 
In relation to Uganda, in its Concluding Observations in 2015, the CESCR similarly expressed its concern at the deteriorating quality of education in public schools. This included hidden costs in public schools on the one hand, and the widening of the gap in access to quality education resulting from the increase in the provision of private education, disproportionately affecting girls and children from poor families, on the other. ${ }^{48}$ Again stressing that the State retains primary responsibility to provide quality education to all children, it recommended that the State party should allocate sufficient resources to the education sector at the same time as strengthening regulations and expanding monitoring and oversight mechanisms over private schools. ${ }^{49}$

This also manifests in relation to international cooperation, where the donor State has a duty not to obstruct the right to free and compulsory education in recipient States. Both the CESCR and the Committee on the Rights of the Child have identified that financial support for private actors for low-cost and private educational projects in developing countries contributes to undermining the quality of free public education and creates segregation and discrimination. ${ }^{50}$ Thus, in its Concluding Observations in relation to Ireland in 2016, the CESCR expressed its concern that some of the official development assistance provided by Ireland was reportedly used for activities in contravention of the social, economic, and cultural rights in the receiving countries. It expressed its particular concern at:

the financial support provided by the State party to private actors for low-cost and private education projects in developing countries, which may have contributed to undermining the quality of free public education and created segregation and discrimination among pupils and students

in contravention of Articles 2, 13, and 14 on the right to education. ${ }^{51}$

Similarly, in its Concluding Observations in relation to the UK in 2016, the Committee on the Rights of the Child expressed its concern at the UK's funding of low-fee, private and informal schools run by for-profit

\footnotetext{
$48 \quad$ CESCR Uganda Concluding Observations (2015), para 36.

49 Ibid.

50 CESCR Concluding Observations Ireland (2016 E/C.12/GBR/CO/6) para 14; CRC Concluding Observations UK (2016).

${ }^{51}$ CESCR Concluding Observations Ireland (2016 E/C.12/GBR/CO/6) para 14 .
} 
business enterprises in recipient States. It recommended that the State party should ensure that its international development cooperation:

supports the recipient States in guaranteeing the right to free compulsory primary education for all, by prioritizing free and quality primary education in public schools, refraining from funding for-profit private schools, and facilitating registration and regulation of private schools. ${ }^{52}$

When a particularly close relationship between the State and the private provider emerges, the private provider might be perceived as carrying out a public function, and therefore subject to the same duties to respect human rights as the State itself. In its recent General Comment on State obligations under the ICESCR in the context of business activities, the CESCR noted that, in accordance with international law:

States parties may be held directly responsible for the action or inaction of business entities: (a) if the entity concerned is in fact acting on that State party's instructions or is under its control or direction in carrying out the particular conduct at issue, as may be the case in the context of public contracts; (b) when a business entity is empowered under the State party's legislation to exercise elements of governmental authority or if the circumstances call for such exercise of governmental functions in the absence or default of the official authorities; or (c) if and to the extent that the State party acknowledges and adopts the conduct as its own. ${ }^{53}$

This effect would depend on the nature of the funding and the subsequent relationship between the State and the private provider.

In recognition of the fact that governments are increasingly using private bodies to carry out functions traditionally carried out by the State, some jurisdictions have developed principles to determine when private bodies can be regarded as carrying out public functions. In some circumstances, this entails holding the State responsible for the private bodies' actions, as above. In others, the body itself is considered to be bound by human rights obligations when carrying out that function. The tests for when a body is carrying out a public function are complex and variable, and cannot be elaborated on here.

52 CRC Concluding Observations UK (2016).

53 CESCR General Comment No. 24 (2017) on State obligations under the International Covenant on Economic, Social and Cultural Rights in the context of business activities, para 11 . 


\section{ii. Duty to Protect}

The duty to protect requires the State to protect individuals from violations of their rights by third parties. In the context of education, it requires the State to ensure that private providers adhere to the standards required of all schools as well as furthering the principles and values which inform the right to education. A key example concerns discipline in schools. In its General Comment on the Right to Education, the CESCR states that a State party must ensure that discipline which is inconsistent with the Covenant does not occur in either public or private educational institutions. ${ }^{54}$ Similarly, the ECtHR has consistently held the State cannot absolve itself of responsibility to secure the right to education of every child by delegating its obligations to private bodies or individuals. Nor is the responsibility of the State limited to the mere establishment of schools; it includes duties in relation to the provision of education within the school and, most specifically, the school's disciplinary system. Thus, when a head-teacher in an independent school administers corporal punishment, this activity would engage the responsibility of the State. ${ }^{55}$

This obligation was further underlined by the ECtHR in the important case of O'Keefe $v$ Ireland, which concerned persistent incidents of sexual abuse by teachers in Church owned and managed schools in Ireland. ${ }^{56}$ The Court found that governments have an inherent positive obligation to protect children from ill treatment, an obligation of acute importance in a primary school context. The obligation was not fulfilled when the Irish State, which was aware of the sexual abuse of children by adults, 'nevertheless continued to entrust the management of the primary education of the vast majority of young Irish children to non-state actors ... without putting in place any mechanism of effective state control against the risks of such abuse occurring, ${ }^{57}$ The State was held to have failed to fulfil its positive obligation to protect the applicant from the sexual abuse to which she was subjected to while at school.

What extra is required if public funding is involved? There is very little direct authority on this issue. Some possibilities, however, can be derived from basic principles. The UN High Commissioner for Human Rights

\footnotetext{
$54 \quad$ CESCR General Comment No. 13 para 41.

55 Costello-Roberts v UK (1995) 19 E.H.R.R. 112 (European Court of Human Rights).

$56 \quad$ O'Keeffe v Ireland (2014) 59 EHRR 15 (ECtHR ).

$57 \quad$ Ibid, para 168.
} 
and the CESCR clearly state that the State should take legislative and other positive measures to discharge its duty to protect. ${ }^{58}$ In the context of public funding of private schools, one highly effective positive measure is through attaching conditions to the provision of funding. A key aspect of the State's positive duty not to be complicit in human rights violations and its duty to protect is to ensure that funding, whether supplied through a contract or other measure, would be conditional on the private provider meeting human rights standards. It is crucial, however, that funding is withdrawn if such conditions are not met, which raises an additional issue about the sustainability of private education and the fate of the students should the State have to rescind funding. ${ }^{59}$ Properly enforced, contract compliance measures are a very effective regulatory tool. ${ }^{60}$

In its General Comment on the Right to Inclusive Education, the Convention on the Rights of People with Disabilities (CRPD) Committee makes the most explicit recommendation on the use of public procurement ${ }^{61}$ to achieve equality for disabled persons in several contexts. First, it states that, given the widespread lack of textbooks and learning materials in accessible formats such as Braille or digital formats, States should consider developing guidelines for the conversion of printed material into accessible formats, and make accessibility a central aspect

58 Report of the United Nations High Commissioner for Human Rights (E/2015/59, 19 May 2015), paras 17-19; Committee on Economic, Social and Cultural Rights, general comment No. 15 (2003) on the right to water (arts. 11 and 12 of the Covenant), para. 21; general comment No. 14 (2000) on the right to the highest attainable standard of health, para. 33; and general comment No. 12 (1999) on the right to adequate food, para. 15.

59 The situation of a publicly funded private school closing in the middle of the year is discussed in Björn Åstrand, 'From Citizens into Consumers: The Transformation of Democratic Ideals into School Markets in Sweden' in Frank Adamson, Björn Åstrand and Linda Darling-Hammond (eds.), Global Education Reform: How Privatization and Public Investment Influence Education Outcomes (Routledge, 2016), 73-109; see also Juma Musjid v Essay (2011) ZACC 13 (South African Constitutional Court).

60 Christopher McCrudden, Buying Social Justice (Oxford University Press, 2007).

${ }_{61}$ Public procurement refers to the purchase by governments and state-owned enterprises of goods, services and works: Organisation for Economic Co-operation and Development (OECD) Directorate for Public Governance, https://www.oecd.org/gov/public-procurement/ (accessed 15 July 2020). 
of education-related procurement. ${ }^{62}$ Second, public procurement should be used to implement the requirement that all new schools be designed and built following accessibility standards, and existing schools should be adapted within a reasonable time frame. ${ }^{63}$ Third, State parties should use mechanisms available under public procurement processes and partnerships with the private sector to allocate budgets to ensure inclusive education for all. Such allocations should prioritize ensuring adequate resources to render education settings accessible, to invest in inclusive teacher education, to provide accessible transport to school, to make appropriate learning materials available, to provide assistive technologies and sign language. and to implement awareness raising strategies to address stigma and discrimination and to reduce bullying. ${ }^{64}$

The UN Guiding Principles on Business and Human Rights give further guidance on the ways in which the State should discharge its duty to protect when it contracts with or legislates for business enterprises to provide services impacting on the enjoyment of human rights. Although these are not specific to the education sphere, they are clearly applicable to the public funding of private education providers. Several principles are relevant in this context. As a start, States should exercise adequate oversight to ensure they meet their international human rights obligations. This entails, as a necessary step, that relevant service contracts or enabling legislation should clarify the State's expectations that these enterprises respect human rights. In addition, they should ensure that they can effectively oversee the enterprises' activities, including through adequate independent monitoring and accountability mechanisms. ${ }^{65}$

The Principles also require States to promote awareness of and respect for human rights by business enterprises with which they conduct commercial transactions, including through terms of contracts. ${ }^{66}$ Where business enterprises are owned or controlled by the State, the latter should

62 CRPD General Comment No. 4 The Right to Inclusive Education para 24.

${ }^{63}$ CRPD General Comment No. 4 The Right to Inclusive Education para 63.

64 CRPD General Comment No. 4 The Right to Inclusive Education para 69.

65 United Nations Human Rights Office of the High Commissioner Guiding Principles on Business and Human Rights: Implementing the UN 'Protect, Respect and Remedy Framework' (New York, US and Geneva, 2011), Principle 5.

$66 \quad$ Ibid, Principle 6. 
take additional steps to protect against human rights abuses. The more the business enterprise relies on taxpayer support, the stronger the State's duty to ensure the enterprise respects human rights. ${ }^{67}$ This is also the case where business enterprises receive substantial support and services from State agencies. The latter might include development agencies and development finance agencies. In these circumstances, States should require due diligence by the agencies themselves and by business enterprises or projects receiving their support, especially where the nature of the business poses a significant risk to human rights.

Thus, the Guiding Principles affirm that the State's duty to protect extends to all situations in which a commercial nexus exists between the State and businesses, including contracting out, privatization, and the purchase of goods and services through public procurement. A recent survey of 20 jurisdictions found that central governments and other public bodies were not fulfilling this duty. In the few jurisdictions that did address human rights, their scope was limited to specific human rights, such as modern slavery, or human rights instruments, such as International Labour Organization (ILO) conventions. ${ }^{68}$ The survey makes no mention of education provision.

A particularly important aspect of the duty to protect in the context of providing public financing is the duty of States as members of multilateral institutions that deal with business related issues, such as international trade and financial obligations. In participating in such institutions, States retain their human rights law obligations. ${ }^{69}$ In General Comment 13, the CESCR emphasizes that international financial institutions, especially the World Bank and International Monetary Fund (IMF):

should pay greater attention to the protection of the right to education in their lending policies, credit agreements, structural adjustment programmes and measures taken in response to the debt crisis ... The adoption of a human rights-based approach by United Nations specialized agencies, programmes and bodies will greatly facilitate implementation of the right to education. ${ }^{70}$

$67 \quad$ Guiding Principles on Business and Human Rights, Principle 4.

68 International Learning Laboratory, Public Procurement and Human Rights: A Survey of Twenty Jurisdictions (July 2016), http://www .hrprocurementlab.org/blog/reports/public-procurement-and-human-rights-a -survey-of-twenty-jurisdictions/ (accessed 20 April 2018).

$69 \quad$ Guiding Principles on Business and Human Rights, para 10.

70 CESCR General Comment 13, para 61. 
Given that these bodies get their mandates through the participation of individual States, it is crucial that States fulfil their duty to protect in relation to education by ensuring that international financial institutions take these obligations seriously.

\section{iii. Duty to Fulfil}

According to the CESCR General Comment on Article 13, the State has the duty to fulfil the availability of education 'by actively developing a system of schools, including building classrooms, delivering programmes, providing teaching materials, training teachers and paying them domestically competitive salaries' ${ }^{71}$ There is little direct reference by the Committee to the implications for the duty to fulfil of the public funding of private education providers. In this subsection, as in the previous one, an attempt is made to extrapolate from the basic principles, and from examples at international, regional, and domestic level, to flesh out such implications.

\section{a. Duty of non-discrimination}

The main area in which the duty to fulfil has traction in relation to public financing of private providers relates to equality and non-discrimination. The background principle is that the duty to fulfil the right to education includes the duty to ensure that the right to education is enjoyed equally and without discrimination on any of the prohibited grounds. In all human rights instruments, the duty not to discriminate is an immediate duty, not subject to progressive realization or maximum available resources. Thus when considering public financing of private providers, these transactions must take care not to discriminate, either directly or indirectly.

The CEDAW Committee has given detailed attention to this duty in the context of gender. In its 2017 General Recommendation on the Right to Education, it notes that in times of economic crises, many State parties make cuts to social services and outsource education to private entities, including religious or community groups or non-governmental organizations (NGOs). The Committee emphasizes that 'privatization has specific negative consequences for girls and women, and in particular girls from 
poorer families, namely, their exclusion from education'. ${ }^{72}$ It therefore recommends both that the State provide universal free and compulsory education, regardless of socio-economic status, and that the State ensure that private actors respect the non-discrimination standards required in public institutions, as a condition of their running private institutions. ${ }^{73}$

In its provision of public financing, the State is also under duty to prevent discrimination on grounds of disability. Both the CESCR and the CRPD have elaborated this duty. In its General Comment on Persons with Disabilities, the CESCR emphasizes that, when public services provision is increasingly privatized, private providers must be subject to both non-discrimination and equality laws in relation to persons with disabilities. ${ }^{74}$ While the Committee accepts that it may be appropriate for governments to rely on private groups to assist persons with disabilities in various ways, this can never absolve governments of their duty to ensure full compliance with ICESCR rights. ${ }^{75}$

Likewise, the CRPD General Comment on Inclusive Education, noting the growth of private sector education, emphasizes that the right to inclusive education extends to the provision of all education, not just that provided by public authorities. State parties must ensure that persons with disabilities can access education in both public and private academic institutions on an equal basis with others. ${ }^{76}$ This means that States must put in place legislative and other measures for the regulation, monitoring, oversight, enforcement, and the adoption of policies as a framework for ensuring that private providers do not infringe the rights of persons with disabilities. Private educational institutions and enterprises should not be permitted to charge additional fees for accessibility and reasonable accommodation and must be prevented from refusing to enrol persons with disabilities on the basis of their impairment. ${ }^{77}$

72 CEDAW General Recommendation No. 36 (2017) on the right of girls and women to education (2017), paras 38-39.

73 CEDAW General Recommendation No. 36 (2017) on the right of girls and women to education (2017), paras 38-39.

$74 \quad$ CESCR General Comment No. 5 Persons with Disabilities (1994), para 11.

75 CESCR General Comment No. 5 Persons with Disabilities (1994), para 12.

76 CRPD Committee General Comment No. 4 (Right to Inclusive Education) (2016), para 24.

77 CRPD Committee General Comment No. 4 (Right to Inclusive Education) (2016), paras 39 and 76. 
Perhaps the most pervasive form of discrimination resulting from privatization of education relates to people living in poverty. Discrimination on grounds of socio-economic status is not expressly mentioned in the relevant treaties. In their General Comments, several of the Committees nevertheless address the issue of discrimination against poorer learners, especially in relation to public funding decisions. In its General Comment on Education, the CESCR stresses that if sharp disparities in spending policies result in differing qualities of education for persons in different geographical locations, this situation might constitute discrimination under the Covenant. ${ }^{78}$ Thus, if public funding of private bodies is provided, it cannot be done in a way which would cause or increase disparities in quality of education for different regions. Given that regional differences are often a proxy for economic disparities, this stipulation is one way of shaping the duty to fulfil so that it does not decrease access to education based on poverty.

The CEDAW Committee addresses poverty as an intersectional issue. The Committee is clear that, at the intersection of poverty and gender, girls and women are most affected by the costs of education. It thus states that State parties should take:

all measures to ensure that user fees and hidden costs do not have a negative impact on girls' and women's access to education. These include the introduction of measures to ensure that girls and women from lower socio-economic strata are not denied access to any level of education because they cannot pay user fees or meet hidden costs. ${ }^{79}$

This means that if the State claims that it is discharging its duty to fulfil the right to education by providing public funding to private providers, it needs to be sure that such funding is provided in a manner which is not discriminatory.

Discrimination in this context is not just about differential quality of schooling. It also requires the State to prevent stigma and stereotyping and to ensure meaningful participation. This stance is made more explicit by the CESRC. In its General Comment on non-discrimination in social and economic rights, it recognizes that a person's social and economic situation may result in pervasive discrimination, stigmatization, and

78 CESCR General Comment No.13, para 35.

79 CEDAW General Recommendation No. 36 (2017) on the right of girls and women to education, para 39. 
negative stereotyping. This can lead to unequal access to the same quality of education as others. It therefore states that individuals and groups of individuals should not be arbitrarily treated on account of belonging to a particular economic or social group within society. ${ }^{80}$ This is a positive duty: the State should not just refrain from discriminating in its own right, it should take concrete, deliberate, and targeted measures to ensure that discrimination in the exercise of Covenant rights is prohibited ${ }^{81}$ Both public and private institutions should be required to develop plans of action to address discrimination. ${ }^{82}$

\section{b. Transparency, accountability, and efficiency}

A second major aspect of the duty in relation to funding of private providers concerns proper accountability, transparency, and efficiency. These have been recently made explicit in CESCR General Comment No. 24 (2017) on State obligations under the ICESCR in the context of business activities. In this General Comment, the Committee expresses its concern that private education institutions may be insufficiently regulated, 'providing a form of education that does not meet minimum educational standards while giving a convenient excuse for States parties not to discharge their own duties towards the fulfilment of the right to education' ${ }^{83}$ It therefore stresses that States always retain the duty to regulate private actors to ensure that services are regularly assessed, adequate, and accessible to all. One important way of ensuring accountability is through participation. This is made clear by the 2017 General Comment, where the CESCR states:

Since privatization of the delivery of goods or services essential to the enjoyment of Covenant rights may result in a lack of accountability, measures should be adopted to ensure the right of individuals to participate in assessing the adequacy of the provision of such goods and services. ${ }^{84}$

80 CESCR General Comment No. 20 Non-discrimination in economic, social and cultural rights (2009) para 35.

81 CESCR General Comment No. 20 Non-discrimination in economic, social and cultural rights (2009) para 36.

82 CESCR General Comment No. 20 Non-discrimination in economic, social and cultural rights (2009) para 38.

83 General comment No. 24 (2017) on State obligations under the International Covenant on Economic, Social and Cultural Rights in the context of business activities para 22 .

$84 \quad$ Ibid, para 22. 
The need for accountability and transparency is particularly clear in relation to tendering to private providers for the provision of materials such as school textbooks, desks and chairs, or buildings. Tender processes are vulnerable to corruption and inefficiency, with the result that learners might be unable to access key materials such as textbooks, which are part of the State's ongoing duty to fulfil the right to education. The duty to fulfil in such cases requires that the State provide alternatives if its contracting partners are not fulfilling their duties.

For example, in a recent series of cases in South Africa, the responsible education authority had contracted out its obligation to provide textbooks to a company which failed at scale to put in place an appropriate system to deliver the textbooks while also pocketing some of the discounts available to the State. ${ }^{85}$ The South African courts held that the State had breached its duty to fulfil the right to education as well as its duty not to discriminate against the learners who had not received their textbooks. ${ }^{86}$

This is also true when the private provider no longer wishes to continue its role as a partner in the provision of education. In such circumstances, the State would be in breach of its duty to fulfil the right to education if it does not take immediate steps to provide alternative free schooling for the affected learners. An example is the South African Constitutional Court case of Juma Musjid, which concerned a faith-based Trust which had allowed a State funded school to operate on its property. ${ }^{87}$ After several years, the Trust decided that it no longer wished to host the school and applied for an eviction order. The South African Constitutional Court held that the public authority responsible for schooling in this context had breached its duties to make alternative arrangements for the affected learners. ${ }^{88}$

It is also important to stress that the correlative of the right to establish private educational institutions in order to permit parents to educate their children according to their own convictions must be a duty to provide alternatives to private education where the latter conflicts with parental convictions. If the only schools available are those with a particular religious ethos, or a wider ideology, the State is required to provide accessible and affordable alternatives.

86 Ibid.

87 Juma Musjid v Essay.

88 Ibid. 
The above principles strongly suggest that funding for some types of privatization is less likely to fulfil human rights principles than others. This can be illustrated by applying Rizvi's three-fold categorization of privatization as delegation, divestment, and displacement. Delegation refers to situations in which the State continues to remain entirely responsible for a function but delegates the production to the private sector. Privatization through divestment occurs when government sheds its responsibility for an enterprise, function, or asset by transferring it to a private agency. This can be through a sale, or even the free transfer of assets to a nominated class of people. Displacement is a passive or indirect process, which occurs when the private sector more or less gradually displaces the government. A major impetus for displacement is through deregulation, where the State abandons its role as guarantor of the right to education on the assumption that market competition will lead to the most efficient provision of services ${ }^{89}$ All of these approaches are driven, to a greater or lesser extent, by a belief in the market as the optimal way of meeting people's needs.

It is possible for funding through delegation to comply with human rights commitments, provided the funding is conditional on adherence to these commitments. Delegation will generally take place through contracts. This makes it possible to enforce human rights commitments as contractually binding requirements, which, if breached, could lead to repudiation of the contract. As mentioned above, properly enforced, contract compliance mechanisms can be highly effective. ${ }^{90}$ At the same time, where such conditions are not effective, or difficult to enforce, the duty to protect would require the State not just to withdraw the funding under this contract, but potentially desist from the kind of funding in question.

On the other hand, divestment, which occurs when government transfers its responsibilities to a private agency, is unlikely to fulfil the State's human rights commitments unless it is accompanied by a strict regulatory environment, which is properly enforced. Unlike delegation, where the State retains control over continuing funding, divestment is by definition a one-off transaction. For example, the sale of property to a private corporation to build a school, possibly at a discounted rate, gives no contin-

89 F. Rizvi. Privatization in Education: Trends and Consequences (UNESCO Education Research and Foresight Working Papers, October 2016), $5-6$.

90 C. McCrudden, Buying Social Justice Equality, Government Procurement, \& Legal Change (Oxford University Press, 2007). 
uing leverage to the State in relation to the subsidy provided. Particularly difficult to constrain is funding which has a displacement effect, that is, where government is displaced more or less gradually by the private sector, usually as a result of deregulation..$^{91}$ Therefore, where public funding of private providers diverts funding from public schools, thereby making quality education less accessible for some children, this would directly infringe the State's duty not to obstruct the right to education of all the children in its jurisdiction. Where funding has a displacement effect of this kind, it is very likely to infringe the State's duties to respect, protect, and fulfil the right to education.

\section{CONCLUSION}

International human rights law clearly establishes that the State must permit educational institutions outside the State system. This preserves individual freedom of opinion, religion, and political conviction against the risk that the State will use the educational system to enforce its own values, religion, or other ideology on individuals. It is also relatively clear that the State generally has no obligation to fund private educational establishments. The chief exception to this occurs under the non-discrimination principle: if the State funds some religious establishments, it might be required to fund others. This also suggests that the State is not wholly prohibited from funding private schooling. In some States, such funding is expressly permitted, although, in others, clear provisions prevent public funding of private schooling.

The question therefore becomes under what conditions public funding of private providers of education would comply with human rights standards. Human rights law establishes that the State retains its responsibility to respect, protect, and fulfil the right to education in relation to private provision, whether or not it provides public funding. However, as the chapter has shown, little direct authority addresses what extra requirements flow from the provision of public funding for such private provision. Nevertheless, the chapter was able to derive several central principles from existing legal materials, usefully considered under the headings of the duty to respect, protect, and fulfil the right to education.

The duty to respect means that public funding to private providers should not undermine or obstruct the right to education of every individ- 
ual, whether in the State itself, or in a recipient of aid. The duty to protect requires the State to make such funding conditional on observance of human rights standards. The duty to fulfil entails that the State should not discriminate in the provision of funding, nor allow funding to lead to further discrimination. This includes discrimination on grounds of socio-economic status. The duty to fulfil also requires the transparency and accountability in the award of funding. More work, however, is necessary to flesh out these principles in relation to the wide range of practical examples of public funding of private education providers.

\section{ACKNOWLEDGEMENTS}

I am grateful to Tom Lowenthal for his helpful comments on this chapter.

\section{BIBLIOGRAPHY}

Åstrand, B., 'From Citizens into Consumers: The Transformation of Democratic Ideals into School Markets in Sweden', in F. Adamson, B. Åstrand and L. Darling-Hammond (eds.), Global Education Reform: How Privatization and Public Investment Influence Education Outcomes (Routledge, 2016), 73-109

Beiter, K., The Protection of the Right to Education by International Law (Martinus Nijhoff Publishers, 2006)

Campbell, M., 'A New Ground Of Discrimination: Rural Remoteness?' (OxHRH Blog, 5 June 2017) http://ohrh.law.ox.ac.uk/a-new-ground-of-discrimination -rural-remoteness (accessed 15 July 2020)

International Learning Laboratory, Public Procurement and Human Rights: A Survey of Twenty Jurisdictions (July 2016) http://www.hrprocurementlab .org/blog/reports/public-procurement-and-human-rights-a-survey-of-twenty -jurisdictions/ (accessed 20 April 2018)

McCrudden, C., Buying Social Justice: Equality, Government Procurement, \& Legal Change (Oxford University Press, 2007)

O'Brien, C., Mehra, A. and Meulen, N., International Learning Laboratory: Public Procurement and Human Rights: A Survey of Twenty Jurisdictions (July 2016) http://www.hrprocurementlab.org/blog/reports/public-procurement-and -human-rights-a-survey-of-twenty-jurisdictions/ (accessed 20 April 2018)

Rizvi, F., Privatization in Education: Trends and Consequences (UNESCO Education Research and Foresight Working Papers, October 2016)

United Nations Human Rights Office of the High Commissioner, Guiding Principles on Business and Human Rights: Implementing the UN "Protect, Respect and Remedy Framework" (New York, US and Geneva 2011) 